\title{
ASCORBIC ACID AND ANTHOCYANIN RETENTION DURING SPRAY DRYING OF ACEROLA POMACE EXTRACT
}

\author{
GERMANO ÉDER GADELHA MOREIRA ${ }^{1}$, \\ HENRIETTE MONTEIRO CORDEIRO DE AZEREDO ${ }^{2,3}$, \\ MARIA DE FÁTIMA DANTAS DE MEDEIROS ${ }^{1}$, EDY SOUSA DE BRITO ${ }^{2}$ and \\ ARTHUR CLÁUDIO RODRIGUES DE SOUZA² \\ ${ }^{1}$ Rio Grande do Norte Federal University \\ Natal, RN, Brazil \\ ${ }^{2}$ Embrapa Tropical Agroindustry \\ Fortaleza, CE, Brazil
}

Accepted for Publication March 21, 2009

\begin{abstract}
The objective of this work was to assess the impact of processing parameters (inlet temperature, 170-200C; drying aid-to-acerola ratio, 2:1-5:1; and percent replacement of maltodextrin by cashew tree gum as drying aid, 0-100\%) on degrees of retention of ascorbic acid (AA) and anthocyanins (AC) during spray drying of acerola pomace extract. The experiment was conducted according to response surface methodology. Degrees of AC and AA retention were impaired by increasing the inlet temperature, and favored by increasing drying aid-to-acerola ratio. Maximum degrees of retention (higher than 95\%) were predicted to be achieved by using an inlet temperature of $170 \mathrm{C}$, with a drying aid-to-acerola ratio of 5:1. Cashew tree gum may or may not be used to replace maltodextrin as the drying aid, without significantly changing the retentions of the compounds of interest.
\end{abstract}

\section{PRACTICAL APPLICATIONS}

Acerola is an important source of ascorbic acid (vitamin C) and anthocyanins (its main pigments, responsible for its red color), compounds of commercial interest, related to their widely reported antioxidant properties, which have been associated to prevention of degenerative diseases. This research involves the preparation of spray-dried acerola extract from an inex-

${ }^{3}$ Corresponding author. H.M.C. de Azeredo, Embrapa Tropical Agroindustry, R. Dra. Sara Mesquita, 2270, CEP 60511-110 Fortaleza, CE, Brazil. TEL: +55 (85) 3391-7236; FAX: +55 (85) 3391-7222; EMAIL: ette@cnpat.embrapa.br 
pensive residue from acerola juice processing. The product may be used as a food additive imparting a red color and/or antioxidant properties to a wide variety of foods. The study also indicates the potential of cashew tree gum, a virtually unknown exsudate from a widely available tree in Brazil, as a maltodextrin replacement as drying aid in spray drying of sugar-rich products such as fruit extracts.

\section{INTRODUCTION}

Acerola (also known as West Indian cherry or Barbados cherry) has been a highly consumed fruit in the last decades, thanks to its antioxidant appeal, related to its high ascorbic acid (AA) contents, that ranges between $1,000 \mathrm{mg} /$ $100 \mathrm{~g}$ and 4,500 mg/100 g (Leung and Foster 1996; Mezadri et al. 2005), as well as the presence of anthocyaninas, which are flavonoid pigments responsible for acerola red color (Chan and Yamamoto 1994; Lima et al. 2003). Brazil is currently the world's leading producer and exporter of acerola (Mezadri et al. 2006), especially as frozen puree and juice (Yamashita et al. 2003). Acerola processing for juice production involves crushing and pressing of the whole fruits, producing a strongly red pomace, which is generally discarded. Considering the presence of antioxidant compounds in this pomace, its further processing seems particularly promising, enhancing the commercial value of the raw fruit and the rentability of acerola processing.

Spray drying is the most commonly used method for drying liquid foods, which are atomized into droplets, and released in a drying chamber with circulating hot air (Jackson and Lee 1991). Although spray drying uses high temperatures (160-230C), the high surface area/volume ratio of the droplets promotes fast drying, and the air flow rate provides a short droplet residence time in the chamber (generally 1-2 s), so that the product is removed from the dryer before the product temperature exceeds 100C. Hence, the occurrence of thermal damage is reduced (Dziezak 1988; Santos et al. 2000). Spray drying of fruit products tends to produce highly hygroscopic and sticky powders, because of the high concentrations of low molecular weight sugars and organic acids, which have low glass transition temperatures $\left(T_{\mathrm{g}}\right)$, being rubbery at the temperatures of the chamber (Bhandari et al. 1997; Bhandari and Hartel 2005). The stickiness is avoided when drying aids (polysaccharides like maltodextrins [MDs] or gums) are added to the fruit product prior to spray drying, as their $T_{\mathrm{g}}$ increasing effect reduces powder hygroscopicity (Bhandari et al. 1997; Bhandari and Hartel 2005; Silva et al. 2006). The gum extracted from cashew tree (Anacardium occidentale) is a complex water soluble heteropolysaccharide, whose chemical structure is quite similar to gum arabic (GA) (Paula et al. 2002; Owusu et al. 2005). The replacement of MDs by 
cashew tree gum (CTG) as drying aid has been previously proved to be advantageous (Moreira et al. 2009), decreasing powder hygroscopicity. An additional advantage of adding a drying aid to fruit extracts prior to spray drying is that it may act as an encapsulating matrix, protecting compounds from oxidation (Clark 2002). AA and anthocyanins (ACs), both present in acerola, are highly prone to oxidative reactions (Moretti et al. 2003; Yamashita et al. 2003; Gliguem and Birlouez-Aragon 2005), and thus their retention during spray drying can be improved by the use of drying aids.

The objective of this work was to evaluate the impact of some processing parameters - namely, spray dryer inlet temperature, drying aid-to-acerola ratio, and percent replacement of MD by CTG as drying aid - on AA and AC retention during spray drying of acerola pomace extract.

\section{MATERIAL AND METHODS}

CTG was extracted from a single cashew tree (Fortaleza, Ceara State, Brazil) and purified as described by Torquato et al. (2004). The acerola pomace (AP) was provided by the company DaFruta Indústria e Comércio S.A. (Aracati, Ceara State, Brazil).

The AP extract (APE) was obtained by grinding the pomace in water (water-to-pomace mass ratio, 5:1) by using a Robot Coupe blender (R201, model Ultra E, produced by BBS Limited, Farnham, Surrey, UK) for 1 min. The diluted pomace was then pressed against a stainless steel mesh cylinder (pore size, $0.3 \mathrm{~mm}$ ) at $5 \mathrm{MPa}$ for $30 \mathrm{~s}$ in a Skay 93 hydraulic press (Skay, São José do Rio Preto, Brazil). The extract was then mixed with CTG and/or MD (DE10) by using a tissue homogenizer AC 620/2 (Ação Científica, Piracicaba, Brazil). The suspension was filtered in a stainless steel sieve $(0.3 \mathrm{~mm}$ mesh $)$ in order to avoid clogging of the atomizer. The spray drying was then conducted in a Mini Spray Dryer Büchi B-290 (Büchi Labortechnik AG, Flawil, Switzerland) under the following operational conditions: peristaltic pump rate, $8.4 \times 10^{-4} \mathrm{~m}^{3} / \mathrm{h}$; aspirator flow rate, $37.5 \mathrm{~m}^{3} / \mathrm{h}$. The other conditions were determined according to a central composite design (Table 1), with three independent variables: inlet temperature (170-200C), drying aid-to-acerola ratio (on a dry basis, 2:1-5:1), and percent replacement of MD by CTG $(0-100 \%)$. The ranges of inlet temperatures and drying aid/acerola ratios (specially the lower limits) were based on preliminary tests, as lower temperatures and/or lower drying aid/acerola ratios led to a very sticky material. The upper limits were defined from literature data, as well as by economic reasons.

The AP, the APE and the spray-dried APE (SDAPE) produced from the several experimental runs were submitted to determinations of total solid 
TABLE 1.

DEGREES OF ANTHOCYANIN AND ASCORBIC ACID RETENTION DURING SPRAY DRYING

\begin{tabular}{rlllll}
\hline \multirow{2}{*}{ Run } & \multicolumn{2}{l}{ Independent variables (process conditions) } & & \multirow{2}{*}{ ACR $(\%)$} & AAR (\%) \\
\cline { 2 - 3 } & IT (C) & DA/A & CTG (\%) & & \\
\hline 1 & 176 & 2.6 & 20.2 & 93.02 & 90.29 \\
2 & 194 & 2.6 & 20.2 & 92.01 & 86.85 \\
3 & 176 & 4.4 & 20.2 & 94.03 & 93.40 \\
4 & 194 & 4.4 & 20.2 & 92.24 & 87.83 \\
5 & 176 & 2.6 & 79.8 & 92.87 & 90.22 \\
6 & 194 & 2.6 & 79.8 & 92.83 & 86.07 \\
7 & 176 & 4.4 & 79.8 & 95.15 & 93.21 \\
8 & 194 & 4.4 & 79.8 & 92.53 & 88.56 \\
9 & 170 & 3.5 & 50.0 & 95.58 & 94.32 \\
10 & 200 & 3.5 & 50.0 & 90.12 & 85.47 \\
11 & 185 & 2.0 & 50.0 & 92.41 & 89.75 \\
12 & 185 & 5.0 & 50.0 & 92.55 & 92.93 \\
13 & 185 & 3.5 & 0.0 & 92.39 & 91.67 \\
14 & 185 & 3.5 & 100.0 & 92.60 & 90.66 \\
15 & 185 & 3.5 & 50.0 & 93.44 & 91.72 \\
16 & 185 & 3.5 & 50.0 & 92.43 & 90.44 \\
17 & 185 & 3.5 & 50.0 & 92.33 & 89.62 \\
\hline
\end{tabular}

IT, inlet temperature; DA/A, drying aid-to-acerola ratio, on a dry basis; CTG, percent replacement of maltodextrin by cashew tree gum; ACR, degree of anthocyanin retention during spray drying; AAR, degree of ascorbic acid retention during spray drying.

content (vacuum oven method) and AA contents (redox titration with 2,6dichloroindophenol), following official methods (AOAC 1995) and total AC content (Lees and Francis 1972).

The recovery of $\mathrm{AC}$ and $\mathrm{AA}$ by extraction was calculated on a dry basis, considering the extraction yield. The calculation of retention of those compounds during spray drying were based on their contents on a dry acerola basis $(\mathrm{CDAB})$ before and after spray drying, i.e., the moisture contents were taken into account, and for SDAPE, also the drying aids (Eq. 1).

$$
C D A B(\%)=\frac{C(\%) \times(D A / A)}{T S(\%)} \times 100
$$

where $C D A B$ is AA or AC content in SDAPE, on a dry acerola basis; $C$ is AA or AC content in SDAPE; $(D A / A)$ is the drying aid-to-acerola ratio; and TS is the total solid content in SDAPE.

The results were analyzed by using the software Minitab 15 (Minitab Inc., State College, PA, USA). The models generated to represent the 
responses were evaluated in terms of their $F$-ratio and $R^{2}$ coefficient. The effects of the independent variables on the physical properties of the powders were studied, and conditions were established, which provided maximum AC and AA retentions by using the Response Optimizer function of Minitab.

\section{RESULTS AND DISCUSSION}

The AP presented a total AC content of $30.67 \mathrm{mg} / 100 \mathrm{~g}$ (on a dry basis, $127.08 \mathrm{mg} / 100 \mathrm{~g})$ and a high AA content $(1,057.48 \mathrm{mg} / 100 \mathrm{~g}$ on a wet basis, $4,380.59 \mathrm{gm} / 100 \mathrm{~g}$ on a dry basis). The APE presented the following contents: total AC, $4.71 \mathrm{mg} / 100 \mathrm{~g}$, corresponding to $104.80 \mathrm{mg} / 100 \mathrm{~g}$ on a dry basis; AA, $163.84 \mathrm{mg} / 100 \mathrm{~g}$, corresponding to $3,645.53 \mathrm{~g} / 100 \mathrm{~g}$ on a dry basis. The recovery of AC $(82.47 \%)$ and AA $(83.22 \%)$ was relatively high. The recovery could be increased by extraction with acidified methanol or ethanol (Kapasakalidis et al. 2006; Amr and Al-Tamimi 2007), but the process would not be so "clean," safe and cheap, and the spray drying would require a device for samples dissolved in organic solvents.

The degrees of retention of $\mathrm{AC}$ and $\mathrm{AA}$ during each spray drying run are presented in Table 1. Losses were lower for AC (5-10\%) than for AA $(6-15 \%)$, indicating the higher thermal susceptibility of the latter. Indeed, AA is considered as one of the most heat sensitive nutrients (Diez et al. 2008). On the other hand, Uddin et al. (2001) related that, when compared with several other microencapsulation techniques, spray drying produced minimum loss of AA.

Linear models (with interactions) were better fitted to data than quadratic ones. The regression coefficients of the generated models and the respective statistical values of interest are presented in Table 2. Although the $R^{2}$ value for the ACR model was relatively low, both models (for ACR and AAR) were highly significant $(P \leq 0.01)$, with nonsignificant lack of fit.

The contour plots (Figs. 1 and 2) indicate the negative impact of the inlet temperature on degree of $\mathrm{AC}$ and $\mathrm{AA}$ retention, i.e., both $\mathrm{AC}$ and $\mathrm{AA}$ were less stable at higher temperatures. This effect is in accordance with those reported by other authors for ACs (Ersus and Yurdagel 2007) and other natural pigments (Cai and Corke 2000; Goula and Adamopoulos 2005; Quek et al. 2007), as well as for AA (Al-Kahtani and Hassan 1990). The retentions of the compounds were enhanced by increasing drying aid-to-acerola ratio. This effect may be attributed to an increased encapsulation efficiency by the polysaccharide matrix, as supported by Wieland-Berghausen et al. (2002) and Jalil and Nixon (1990). Some articles have reported improved stability of ACs (Chandra et al. 1993; Gradinaru et al. 2003) and AA (Kirby et al. 1991; Uddin et al. 2001; Lee et al. 2004; Righetto and Netto 2006; Pereira et al. 2009) by using polysaccharide matrices. Finally, the percent replacement of MD by CTG had 
TABLE 2 .

REGRESSION COEFFICIENTS (IN THE CODIFIED FORM) AND STATISTICAL VALUES FOR THE MODELS

\begin{tabular}{|c|c|c|c|c|}
\hline \multirow[t]{2}{*}{ Factor } & \multicolumn{2}{|l|}{ ACR } & \multicolumn{2}{|l|}{ AAR } \\
\hline & Coefficient & $P$ & Coefficient & $P$ \\
\hline Mean & 92.85 & $<0.01$ & 90.18 & $<0.01$ \\
\hline$x_{1}$ & -1.07 & $<0.01$ & -2.39 & 0.01 \\
\hline$x_{2}$ & 0.25 & 0.24 & 1.09 & $<0.01$ \\
\hline$x_{3}$ & 0.18 & 0.40 & -0.15 & 0.63 \\
\hline$x_{1} * x_{2}$ & -0.42 & 0.15 & -0.33 & 0.42 \\
\hline$x_{1} * x_{3}$ & 0.02 & 0.95 & 0.03 & 0.95 \\
\hline$x_{2} * x_{3}$ & 0.09 & 0.74 & 0.17 & 0.67 \\
\hline$F_{\text {regression }}$ & \multicolumn{2}{|c|}{$5.44(P=0.01)$} & \multicolumn{2}{|c|}{$13.34(P<0.01)$} \\
\hline$F_{\text {lack of fit }}$ & \multicolumn{2}{|c|}{$1.63(P=0.44)$} & \multicolumn{2}{|c|}{$1.09(P=0.56)$} \\
\hline$R^{2}$ & \multicolumn{2}{|l|}{$76.56 \%$} & \multicolumn{2}{|l|}{$88.89 \%$} \\
\hline
\end{tabular}

ACR, degree of anthocyanin retention during spray drying; AAR, degree of ascorbic acid retention during spray drying; $x_{1}$, inlet temperature; $x_{2}$, drying aid-to-acerola ratio; $x_{3}$, percent replacement of maltodextrin by cashew tree gum.

a slight tendency to increase the degree of retention of $\mathrm{AC}$ and $\mathrm{AA}$, indicating that maybe CTG was more efficient than MD for protecting those highly degradable compounds. However, this effect was not significant $(P<0.05)$. Other studies evaluating CTG effects on retention of chemical compounds during spray drying were not found in the literature. On the other hand, considering the above-mentioned high similarity between CTG and GA, it is worth referring to the studies by Dib Taxi et al. (2003) and Righetto and Netto (2006), who observed that GA was more effective than MD to improve AA retention during spray drying of camu-camu and green acerola, respectively.

Within the experimental ranges studied, the predicted conditions to simultaneously provide the maximum possible retention of $\mathrm{AC}$ and $\mathrm{AA}$ were: inlet temperature, 170C; drying aid-to-acerola ratio, 5:1, the drying aid being $100 \%$ CTG. Under such conditions, AA retention was predicted to be $97.14 \%$, and $\mathrm{AC}$ retention, $96.78 \%$. However, reassuring the nonsignificance of the effects of replacing MD, the same conditions except by using 100\% MD instead of $100 \%$ CTG resulted in quite similar predicted retention degrees (96.80\% for AA, 95.76\% for ACs). Thus, it can be stated that the best experimental conditions are: an inlet temperature of $170 \mathrm{C}$, and a drying aid-toacerola ratio, 5:1. MD may or may not be replaced (totally or partially) by CTG, without significant changes in retention of the compounds of interest. The choice of the drying aid may be driven by economic factors and 

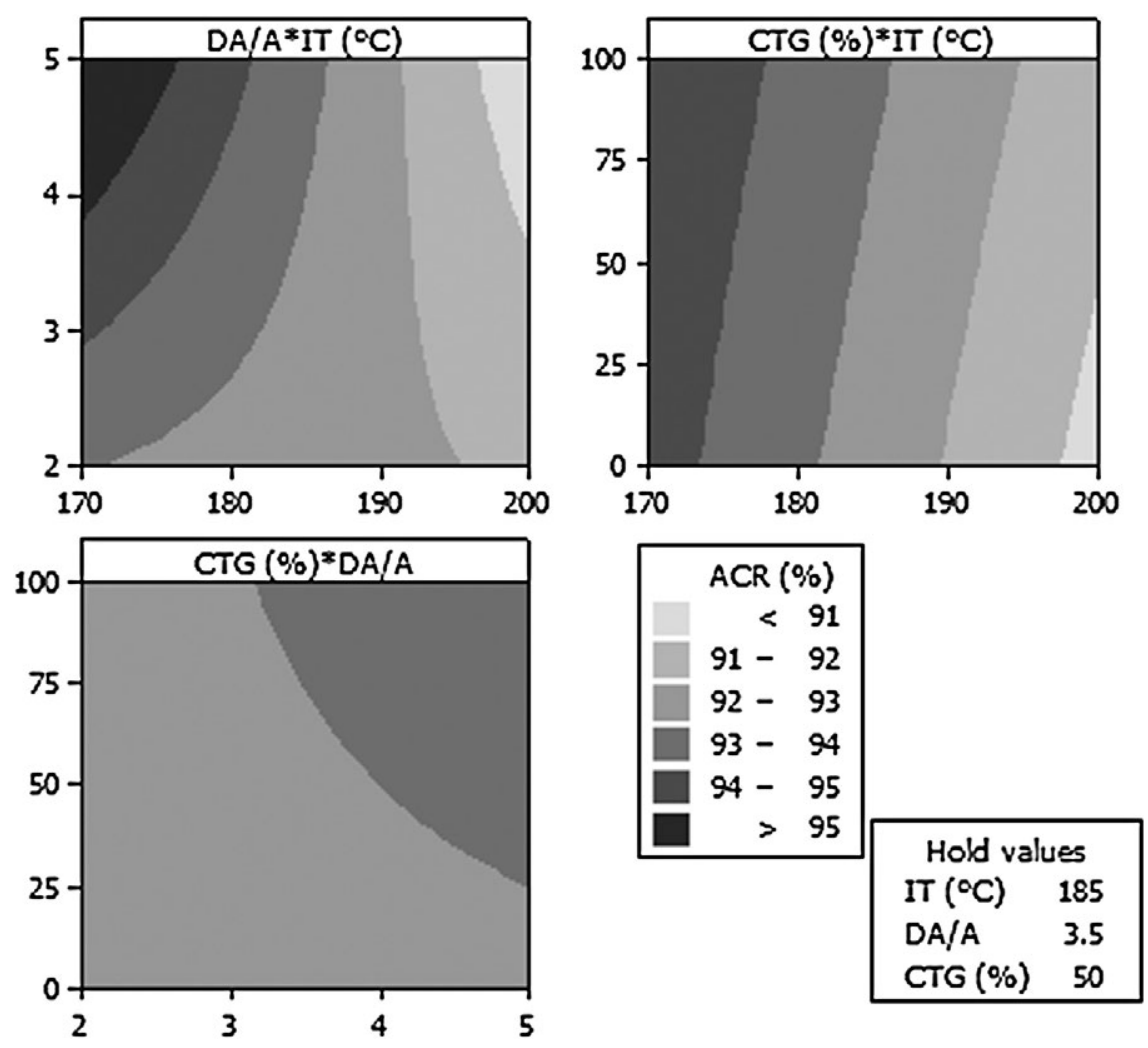

FIG. 1. CONTOUR PLOTS FOR DEGREES OF ANTHOCYANIN RETENTION DURING SPRAY DRYING

IT, inlet temperature; DA/A, drying aid-to-acerola ratio; CTG, percent replacement of maltodextrin by cashew tree gum.

availability. Until today, CTG has not been produced in a commercial scale, but its potential to replace GA may, in a near future, motivate proper industrial exploration, making this gum widely available.

\section{CONCLUSIONS}

Anthocyanin losses were lower than those of ascorbic acid during spray drying, indicating the higher thermal susceptibility of the latter.

The retention of the compounds of interest during spray drying was favored by lower inlet temperatures and higher drying aid-to-acerola ratio. The 

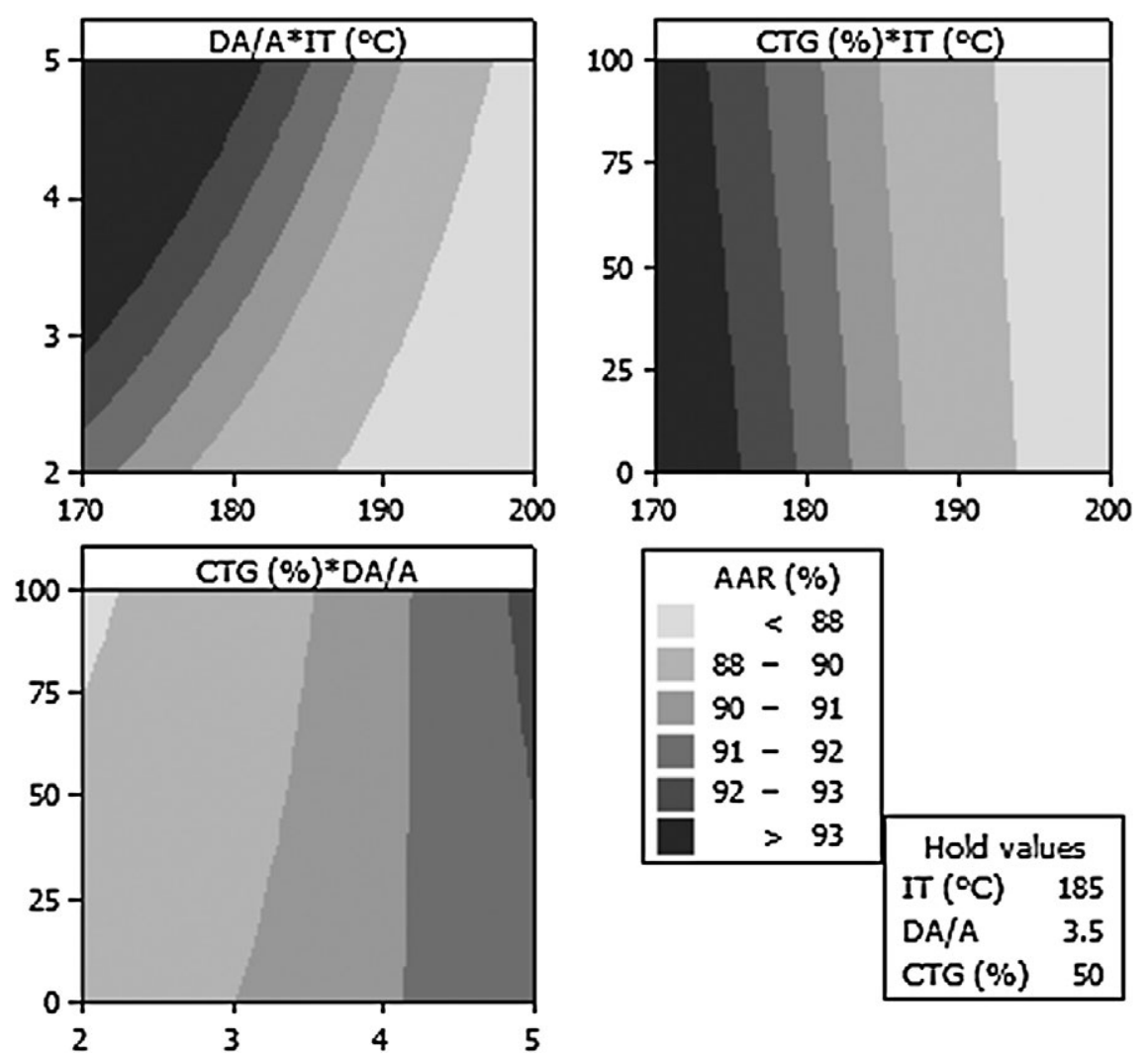

FIG. 2. CONTOUR PLOTS FOR DEGREES OF ASCORBIC ACID RETENTION DURING SPRAY DRYING

IT, inlet temperature; DA/A, drying aid-to-acerola ratio; CTG, percent replacement of maltodextrin by cashew tree gum.

effects of replacing maltodextrin (MD) by cashew tree gum (CTG) as drying aid were not significant. Degrees of retention higher than $95 \%$ during spray drying were predicted to be achieved by using an inlet temperature of $170 \mathrm{C}$, with a drying aid-to-acerola ratio of 5:1, being the drying aid MD, CTG or a combination of both.

\section{ACKNOWLEDGMENT}

The authors are grateful to Conselho Nacional de Desenvolvimento Científico e Tecnológico, Brazil for the financial support. 


\section{REFERENCES}

AL-KAHTANI, H.A. and HASSAN, B.H. 1990. Spray drying of roselle (Hibiscus sabdariffa L.) extract. J. Food Sci. 55, 1073-1076.

AMR, A. and AL-TAMIMI, E. 2007. Stability of the crude extracts of Ranunculus asiaticus anthocyanins and their use as food colourants. Int. J. Food Sci. Technol. 42, 985-991.

AOAC. 1995. Official Methods of Analysis of AOAC International, 16th Ed., AOAC, Arlington, MA.

BHANDARI, B.R., DATTA, N. and HOWES, T. 1997. Problems associated with spray drying of sugar-rich foods. Drying Technol. 15, 671684.

BHANDARI, B.R. and HARTEL, R.W. 2005. Phase transitions during food powder production and powder stability. In Encapsulated and powdered foods, (C. Onwulata, ed.) pp. 261-292, Taylor \& Francis, Boca Raton.

CAI, Y.Z. and CORKE, H. 2000. Production and properties of spray dried amaranthus betacyanin pigments. J. Food Sci. 65, 1248-1252.

CHAN, H.T., JR. and YAMAMOTO, H.Y. 1994. Kinetics of anthocyanin decomposition in acerola juice. ASEAN Food J. 9, 132-135.

CHANDRA, A., NAIR, M.G. and IEZZONI, A.F. 1993. Isolation and stabilization of anthocyanins from tart cherries (Prunus cerasus L.). J. Agric. Food Chem. 41, 1062-1065.

CLARK, J.P. 2002. Food encapsulation: Capturing one substance by another. Food Technol. 56, 63-65.

DIB TAXI, C.M.A., MENEZES, H.C., SANTOS, A.B. and GROSSO, C.R.F. 2003. Study of the microencapsulation of camu-camu (Myrciaria dubia) juice. J. Microencapsul. 20, 443-448.

DIEZ, R., ORTIZ, M.C., SARABIA, L. and BIRLOUEZ-ARAGON, I. 2008. Potential of front face fluorescence associated to PLS regression to predict nutritional parameters in heat treated infant formula models. Anal. Chim. Acta. 606, 151-158.

DZIEZAK, J.D. 1988. Microencapsulation and encapsulated ingredients. Food Technol. 42, 136-151.

ERSUS, S. and YURDAGEL, U. 2007. Microencapsulation of anthocyanin pigments of black carrot (Daucus carota L.) by spray drier. J. Food Eng. $80,805-812$.

GLIGUEM, H. and BIRLOUEZ-ARAGON, I. 2005. Effects of sterilization. packaging, and storage on vitamin $\mathrm{C}$ degradation, protein denaturation, and glycation in fortified milks. J. Dairy Sci. 88, 891-899.

GOULA, A.M. and ADAMOPOULOS, K.G. 2005. Stability of lycopene during spray drying of tomato pulp. Lebensm.-Wiss. Technol. 38, 479487. 
GRADINARU, G., BILIADERIS, C.G., KALLITHRAKA, S., KEFALAS, P. and GARCIA-VIGUERA, C. 2003. Thermal stability of Hibiscus sabdariffa L. anthocyanins in solution and in solid state: Effects of copigmentation and glass transition. Food Chem. 83, 423-436.

JACKSON, L.S. and LEE, K. 1991. Microencapsulation and the food industry. Lebensm.-Wiss. Technol. 24, 289-297.

JALIL, R. and NIXON, J.R. 1990. Microencapsulation using poly(DL-lactic acid). III: Effect of polymer molecular weight on the release kinetics. J. Microencapsul. 7, 357-374.

KAPASAKALIDIS, P.G., RASTALL, R.A. and GORDON, M.H. 2006. Extraction of polyphenols from processed black currant (Ribes nigrum L.) residues. J. Agric. Food Chem. 54, 4016-4021.

KIRBY, C.J., COXON. D.T., RIGBY, N., WHITTLE, C.J. and LAW, B.A. 1991. Stabilization of ascorbic acid by microencapsulation in liposomes. Int. J. Food Sci. Technol. 26, 437-449.

LEE, J.B., AHN, J., LEE, J. and KWAK, H.S. 2004. L-ascorbic acid microencapsulated with polyacylglycerol monostearate for milk fortification. Biosci. Biotechnol. Biochem. 68, 495-500.

LEES, D.H. and FRANCIS, F.J. 1972. Standardization of pigment analyses in cranberries. HortScience 7, 83-84.

LEUNG, A.Y. and FOSTER, S. 1996. Encyclopedia of Common Natural Ingredients Used in Food, Drugs, and Cosmetics, 2nd Ed., pp. 6-7, Wiley, New York, NY.

LIMA, V.L.A., MELO, E.A., MACIEL, M.I.S. and LIMA, D.E.S. 2003. Avaliação do teor de antocianinas em polpa de acerola congelada proveniente de frutos de 12 diferentes aceroleiras (Malpighia emarginata D.C.). Ciênc. Tecnol. Aliment. 23, 101-103.

MEZADRI, T., PÉREZ-GÁLVEZ, A. and HORNERO-MÉNDEZ, D. 2005. Carotenoid pigments in acerola fruits (Malpighia emarginata DC) and derived products. Eur. Food Res. Technol. 220, 63-69.

MEZADRI, T., FERNÁNDEZ-PACHÓN, M.S., VILLAÑO, D., GARCÍAPARRILLA, M.C. and TRONCOSO, A.M. 2006. El fruto de la acerola: Composición. características productivas e importância econômica. Arch. Latinoam. Nutr. 56, 101-109.

MOREIRA, G.E.G., COSTA, M.G.M., SOUZA, A.C.R., BRITO, E.S., MEDEIROS, M.F.D. and AZEREDO, H.M.C. 2009. Physical properties of spray dried acerola pomace extract as affected by temperature and drying aids. Lebensm.-Wiss. Technol. Food Sci. Technol. 42, 641-645.

MORETTI, C.L., ARAÚJO, A.L. and MATTOS, L.M. 2003. Evaluation of different oxygen, carbon dioxide and nitrogen combinations employed to extend the shelf life of fresh-cut collard greens. Hortic. Bras. 21, 676680 . 
OWUSU, J., OLDHAM, J.H., ODURO, I., ELLIS, W.O. and BARIMAH, J. 2005. Viscosity studies of cashew gum. Trop. Sci. 45, 86-89.

PAULA, H.C.B., GOMES, F.J.S. and PAULA, R.C.M. 2002. Swelling studies of chitosan/cashew gum physical gels. Carbohydr. Polym. 48, 313-318.

PEREIRA, H.V.R., SARAIVA, K.P., CARVALHO, L.M.J., ANDRADE, L.R., PEDROSA, C. and PIERUCCI, A.P.T.R. 2009. Legume seeds protein isolates in the production of ascorbic acid microparticles. Food Res. Int. $42,115-121$.

QUEK, S.Y., CHOK, N.K. and SWEDLUND, P. 2007. The physicochemical properties of spray-dried watermelon powders. Chem. Eng. Process. 46, 386-392.

RIGHETTO, A.M. and NETTO, F.M. 2006. Vitamin C stability in encapsulated green West Indian cherry juice and in encapsulated synthetic ascorbic acid. J. Sci. Food Agric. 86, 1202-1208.

SANTOS, A.B., FERREIRA, V.P. and GROSSO, C.R.F. 2000. Microcápsulas - uma alternativa viável. Microencapsulação de produtos sensíveis à oxidação: Oleo-resina de páprica. Biotecnolog. Ciênc. Desenvolv. 16, $26-30$.

SILVA, M.A., SOBRAL, P.J.A. and KIECKBUSCH, T.G. 2006. State diagrams of freeze-dried camu-camu (Myrciaria dubia [HBK] Mc Vaugh) pulp with and without maltodextrin addition. J. Food Eng. 77, 426-432.

TORQUATO, D.S., FERREIRA, M.L., SÁ, G.C., BRITO, E.S., PINTO, G.A.S. and AZEVEDO, E.H.F. 2004. Evaluation of antimicrobial activity of cashew tree gum. World J. Microbiol. Biotechnol. 20, 505-507.

UDDIN, M.S., HAWLADER, M.N. and ZHU, H.J. 2001. Microencapsulation of ascorbic acid: Effect of process variables on product characteristics. J. Microencapsul. 18, 199-209.

WIELAND-BERGHAUSEN, S., SCHOTE, U., FREY, M. and SCHMIDT, F. 2002. Comparison of microencapsulation techniques for the watersoluble drugs nitenpyram and clomipramine $\mathrm{HCl}$. J. Control Release 85, $35-43$.

YAMASHITA, F., BENASSI, M.T., TONZAR, A.C., MORIYA, S. and FERNANDES, J.G. 2003. Produtos de acerola: Estudo da estabilidade de vitamina C. Ciênc. Tecnol. Aliment. 23, 92-94. 